This is the final peer-reviewed Manuscript, NOT the published version of the article 


\title{
Variations of Vileness: An Introduction
}

\section{Jonathan Patterson and Emilia Wilton-Godberfforde St Hilda's College, University of Oxford, and The Open University, UK}

\begin{abstract}
This special issue of Early Modern French Studies is devoted to the subject of vileness and the latent preoccupations it reveals in Renaissance and Baroque French culture (1500-1650). The guest editors explain how the following contributions will expose the significance of the vile in three key regards: i) the heuristic value of repulsive bodies; ii) a search for transcendent beauty in death and decay; iii) revilement along linguistic, social and political lines. In and between these wider phenomena, variations of vileness tellingly illuminated the difficulties of calibrating moral and aesthetic categories with those of a changing socio-political hierarchy.
\end{abstract}

\section{KEYWORDS}

vile, abject, death, disgust, gruesome, vilain, Renaissance, Baroque 
In the early modern world, vileness, in its various forms, was demonstrably shunned. These different forms included (but were by no means limited to) wanton dishonesty and deception; ${ }^{1}$ a grubby love of money; ${ }^{2}$ the inordinate appetites of those indulging in obscenities or other sexual perversion; ${ }^{3}$ those who were thought to be descended from inferior human stock, who lacked social status, value or refinement, and who seemingly contributed little to the state; ${ }^{4}$ the ugly, grotesque, abjectly disfigured, shameful, degrading and dirty things of life that evoked a reaction of disgust from the pit of one's stomach. ${ }^{5}$ Yet these manifold variations of the vile intrigued, titillated, and compelled the imagination of many early modern thinkers, writers, and artists, whose creations are now eliciting a range of modern interpretations and scholarly investigations. Those who are familiar with this scholarship will readily appreciate that early modern thinking on vileness was irreducible to a single definition - modern or early modern. 'The vile' is at its most productive when used a descriptor that moves between a number of concepts (as adumbrated above) and endogenous terms (as will be discussed). Both experts and those less familiar with the linguistic and conceptual terrain will gain insight, we hope, from further reflection on what directed the vile in its shifts between differing but neighbouring forms: the raison d'être for this special issue of Early Modern French Studies.

The contribution of this special issue is distinctive in that it explores how French literary reflection on different aspects of the vile moved along - and invited reconsideration of - three strands of cultural preoccupation running through the period 1500-1650. To that extent, the seven studies presented here collectively form an historically-oriented undertaking. Taking a long view of these studies, two threads stand out: firstly, an exploration of the heuristic value of repulsive bodies, and a further, corollary search for signs of transcendent beauty, nobility and grandeur in the all-too base materiality of a creation in death and decay. French literary engagement in these twin preoccupations with vileness traversed the sixteenth century and stretched out into the early decades of the seventeenth. A third strand of literary engagement, moreover, visibly surfaced towards the end of the sixteenth century, as various groups and castes were routinely pronounced vile and thus unfit to rule. Such revilement gained impetus from France's deeply vexing problem of désordre, ramified increasingly along social, political and linguistic lines, in a climate of civil-religious war. These disorderly and violent times accentuated a long-term erosion of traditional privileges held by the nation's ancient noble families - whose assumed superiority over 'vile commoners' now looked increasingly open to challenge, not least in literature. Literary texts were, in short, a fertile environment for exposing

\footnotetext{
${ }^{1}$ See Emilia Wilton-Godberfforde, Mendacity and the Figure of the Liar in Seventeenth-Century French Comedy (London; New York: Routledge, 2017).

${ }^{2}$ See Jonathan Patterson, Representing Avarice in Late Renaissance France (Oxford: Oxford University Press, 2015); and a series of nine articles examining sixteenth- and seventeenth-century material, edited by Bruno Méniel in Seizième Siècle, no.4 (2008), 7-170.

${ }^{3}$ Obscenity has proved to be a particularly rich field of inquiry within the history of sexuality. See particularly Obscénités renaissantes, ed. by Hugh Roberts, Guillaume Peureux and Lise Wajeman (Geneva: Droz, 2011); Nicholas Hammond, Gossip, Sexuality and Scandal in France (1610-1715) (Oxford and New York: Peter Lang, 2011); Joan DeJean, The Reinvention of Obscenity: Sex, Lies, and Tabloids in Early Modern France (Chicago and London: University of Chicago Press, 2002); The Invention of Pornography: Obscenity and the Origins of Modernity, 1500-1800, ed. by Lynn Hunt (New York: Zone, 1993).

${ }^{4}$ See David Whitford, The Curse of Ham in the Early Modern Era: The Bible and the Justifications for Slavery (Farnham: Ashgate, 2009); Jonathan Patterson, “Viles personnes”: The Plebeian Multitudes in Charles Loyseau’s Traité des ordres', The Seventeenth Century, 31 (2016), 71-94.

${ }^{5}$ For a recent early modern exploration of disgust, driven by affect theory and anthropological approaches, see especially the collective volume by Natalie K. Eschenbaum and Barbara Correll, Disgust in Early Modern English Literature (London; New York: Routledge, 2016).
} 
how judgements upon the disgusting and the reviled might be socially, politically, or religiously motivated, and, in many cases, subject to aesthetic notions of 'taste' that were far from immutable. ${ }^{6}$

The seven studies of this special issue engage specifically with one or more intertwining threads of the vile, in prose, poetic and dramatic material that in some respects coincides with modern notions of "Renaissance" or "Baroque". 7 Rather than rely overmuch on these categories, however, it will be useful first to take a closer look at what (and who) fomented a critical interest in vileness in sixteenth- and early seventeenth-century France. François Rabelais is a key point of reference. By the advent of the Fifth Book (1564), the vile has become the modus operandi of a Rabelaisian narrator who has made a literary career out of selfconscious, innovative reflections on the problematic nature of his own enterprise. ${ }^{8}$ In the prologue to the Cinquiesme Livre, the narrator proudly presents himself as a 'petit riparographe' - a title suggesting a nod to the Elder Pliny, ${ }^{9}$ and which signifies a painter/ storyteller of vile and humble things. Here then, Rabelais makes explicit an essential aesthetic principle of his comic works: depictions of the vile therein amount to an art form. Hence, the many lowly trivialities that lace his writing now appear to be claimed as objects of intrinsic interest; objects that are deliberately not idealized, but rather stylized in their very vileness to the point of being unmistakably provocative. The self-styled 'petit riparographe' adamantly derives inspiration from his local and earthy language. From beans to dung beetles, Rabelais's strikingly vulgar portraits of vile things exhibit a down-to-earth materiality that is grotesquely exaggerated in his most celebrated object of all - the human body. Defecating, urinating, farting and copulating exuberantly, Rabelaisian grotesque bodies continually display their potential as signs of something far less abject: the onset of a new creation, no less earthy, but imbued, some would say, with a divine-like spark of wisdom. ${ }^{10}$

The paradoxical prospect of concealed sagacity transcending its repulsive exteriors was a favourite Renaissance literary theme, exemplified most tellingly in the person of Socrates. The ugliest of Ancient philosophers was also the wisest: a profound challenge, therefore, to popular models of physiognomy that would read facial deformities as signs of base character. Some of the most thoughtful - and troubling - reflections in this vein are those found in Michel de Montaigne’s 1588 essay, 'De la phisonomie' (Essais, III.12). This essay uses the topos of Socrates's 'si vile forme' shrouding a beauteous soul as a compositional model for writing that intentionally penetrates the 'face-value' of apparently unpromising peoples and scenarios. ${ }^{11}$

\footnotetext{
${ }^{6}$ See further Michael Moriarty, Taste and Ideology in Seventeenth Century France (Cambridge: Cambridge University Press, 1988).

${ }^{7}$ As descriptors, the terms "Renaissance" and "Baroque" are not without their difficulties, being liable to imply a misleadingly fixed sense of periodization. "Renaissance” (used here of material that self-consciously regenerates its present concerns from traces of the Ancient and Medieval world) is a serviceable descriptor of the texts studied by William McKenzie, Emma Herdman, Neil Kenny, and Marie-Claire Thomine-Bichard. "Baroque", (understood here as an a-posteriori descriptor for works of art and literature favouring instability, transition, lurid contrasts, and gruesome spectacles of death) would accordingly fit the writings studied by Richard Parish and Joseph Harris. Neither descriptor, however, lends itself adequately to the vitriolic pamphlets studied by Emma Claussen, which are much more heavily invested in a topical rhetoric of hatred germane to the political context of France in the late 1580s and early 1590s.

${ }^{8}$ This is not the place to debate how much of the Cinquiesme Livre was written by Rabelais: for a useful summary of the debate, see Richard Cooper's 'Etat présent' on the Cinquiesme Livre, in Le Cinquiesme Livre: actes du colloque international de Rome (16-19 octobre 1998), ed. by Franco Giacone (Geneva: Droz, 2001), pp. 9-22.

${ }^{9}$ Pliny the Elder, Natural History, XXXV.112, speaks of one Pyreicus, an artist who specialised in modest subjects (donkeys, foodstuffs), and whom Rabelais links to the humble talent of Aesop.

${ }^{10}$ See Claude La Charité, 'Panurge est-il “Thalamite” ou thélémite? Le style de petit "riparographe” de Rabelais: l’apologue sans morale de l'ane et du roussin', in Le Cinquiesme Livre, pp. 455-66.

11 See Raymond La Charité, “'Of Physiognomy”: The Staging and Reading of Facial Narrative’, in Approaches to Teaching Montaigne's Essays, ed. by Patrick Henry (New York: Modern Language Association of America,
} 
Caught up in the ravages of civil-religious war, Montaigne looks to his lowly peasant neighbours for their pragmatic disregard of death - a naïve indifference which seems consonant with the Socratic dictum that one should always choose what appears to be the simplest and most natural course of action. Curiously, as Montaigne goes on to explain, Socrates himself was unable to do this when confronting capital punishment before an Athenian court. Socrates's final, obstinate desire for principled martyrdom inevitably compromised the downto-earth wisdom he had hitherto lived out. ${ }^{12}$ At this point, we infer, his 'si vile forme' now testifies to an unexpected, degrading moral narcissism.

French literary representation of vileness, as these examples from Montaigne and Rabelais attest, was far from simplistic. At its most subtle, its understanding of the vile moved in step with a critical regard on both the Ancient and present world: one that was attuned to where unsettled matters of morality, aesthetics, social class, politics, and (not least) death might variously unsettle what it meant to be vile. Points of such disturbance are identified and explored further in the following articles, all of which in their different way, investigate the extent to which perception of a vile being, body, or object might include a degree of misrecognition. Emma Herdman's opening study, centring on the Epîtres de l'Amant Vert (1505-11) of Jean Lemaire de Belges (c.1473-1524) considers how Renaissance representation of birds confronted the problem of misrecognizing human values as avian ones. Birds, it would seem, tended to flit between more static human standards of reprehensibility and comeliness; and they hovered indeterminately between differing human conceptions of the vile. The suicidal parrot narrator in Lemaire's poem, crushed in the jaws of a dog, sees himself as a wretched creature nonetheless destined for a noble afterlife. His thoughts of immortality hint at an almost manly nobility of mind, supported by a 'gent corpz': the attractive green plumage he boasted in life. Yet his tragically staged suicide is undercut by what triggered it: an undying shame at his irrepressible, inappropriate chirpiness following the passing of his royal mistress (Lemaire's patron), Marguerite d'Autriche. Lemaire, in Herdman's analysis, demonstrates a fine grasp of the serio-comic potential of the liminal status of a parrot that parrots humans but remains a pretty little green parrot unable to shake off his reprehensible loquacious traits.

Elsewhere, however, the potential rift between appearance and character was no laughing matter; indeed, as William McKenzie shows, it was a most serious concern of imitative poetics. Taking Petrarch's Canzone 129 as a crossroads for understanding the role of vileness in Renaissance love lyric, McKenzie explores what was a stake for a self-abasing poet to contemplate appearing precious in the eyes of his beloved. Underlying any such hope, McKenzie shows, is a Biblical, prophetic gesture successively re-interpreted by St Augustine and Petrarch as a formidable challenge to distinguish signs of divinity in a corrupted creation. As a latecomer in this Augustinian-Petrarchan tradition, Pierre de Ronsard (1524-85) faced the same predicaments: can a poet separate the precious from the vile without sinful presumption? A promising solution was to project his beloved's image onto the natural world. Surely, her near-divinity would be enough to raise nature out its post-lapsarian corruption? And yet the poet's fantasies of his lady are themselves inescapably a part of that corruption, insofar as they are the product of his libidinal self-projection. Obsessed by this desire, Ronsard's poet, in a parallel way to Montaigne's Socrates, is beset by a vile narcissism: stubbornly blaming everyone but himself for his predicament, he finds himself engulfed by 'fausse et vaine illusion' that amounts to a frustratingly alienating, solitary existence.

The frustration of the poet, grappling with the limitations of his fallen desires, is handled more optimistically in sacred lyric composed soon after Ronsard. Exploring the vast

1994), pp. 166-72; Lawrence Kritzman, The Fabulous Imagination: On Montaigne’s Essays (New York: Columbia University Press, 2009), pp. 137-53.

${ }^{12}$ Kritzman, The Fabulous Imagination, p. 149. 
Théorèmes sur le sacré mystère de notre Rédemption (1613-21) of Jean de La Ceppède (1550 -1623), Richard Parish shows how an intimately reverent knowledge of the crucified and resurrected Christ can still be possible for a self-vilifying poet all too conscious of his spiritual shortcomings. The poet's solution, argues Parish, exemplifies a hugely expansive CounterReformation devotional focus on the wounds of Christ. La Ceppède's procedure is to produce a lurid focus on the physical sufferings and secretions of Christ's broken body. The effusive outpourings of this 'objet déplorable', however, cannot be placed in the same aesthetic order as those of the Rabelaisian corps grotesque. The ludic, earthy vileness of the latter has no place in La Ceppède's work. La Ceppède is not so much a riparograph as a keen meditator on small things that have ceased to be vile: just as Christ's 'Symbolique fange', his clay and spittle, restored sight to the blind (John 9), so the 'sang' and 'crachats' of his crucified body may bring a degree of spiritual wholeness to a penitential poet and reader who contemplates them. In La Ceppède, each and every vile disfiguration of Christ's body must be misrecognized, so as to suggest all the more forcefully the eventual glorious beauty of his still-wounded resurrection body. A call, then, for admiratio (in the Baroque sense of experiencing a gruesome object as irreducibly noble) rather than a sense of disgust. ${ }^{13}$ It should be noted here, then, that vileness is not a simple synonym of gruesome. Although a gruesome spectacle may be grotesque and contain vile elements within it, its distinctly shocking and macabre qualities are not constituent features of vileness where they occur in these early modern devotional representations. What might be repugnant in the real world becomes distinctly less so in a fictional space. ${ }^{14}$

A strong devotion to the gruesome anatomy of Christ notwithstanding, seventeenthcentury culture would make the body in its death-throes an almost unspeakable abject - a state of bodily vileness famously echoed in Julia Kristeva's Pouvoirs de l'horreur (1980). Traditional early modern medical beliefs held that dead bodies spewed out infected air, and thus had to be expunged in order to maintain propriety and prevent the spread of infection. Joseph Harris's article, however, reveals a persistent fascination in lingering corpses throughout the oeuvre of Pierre Corneille (1606-84): one that would test the boundaries of squeamish sensibilities and also those of moral-aesthetic continuities. ${ }^{15}$ As plays such as $L a$ Mort de Pompée (1643) attest, Corneille's Baroque depictions of battle gore abound with grotesque, dismembered bodies exhaling rotten breath. ${ }^{16}$ Unusually, these entities are qualified neither as 'vil', nor 'bas', nor 'abject' - such epithets, Harris demonstrates, are tellingly displaced from an aesthetic to a moral register reserved for living villains. Recalling McKenzie's piece, an equivocal separation of the precious from the base takes effect here. At no point is the mutilated Cornelian hero held to be vile. Instead, in Harris's reading, the Roman hero's desecrated, incinerated bodily matter resolutely retains a transcendent moral integrity -

\footnotetext{
${ }^{13}$ Parallels may be sought in fine art: see for instance 'Christ displaying his Wounds' (c. 1625-35, Perth Museum and Art Gallery) by Giovanni Antonio Galli (called Lo Spadarino), for an exposition of stigmata that is disturbingly admirable but without overtones of vileness.

14 This was a focus of discussion in later seventeenth-century poetics. As Boileau stressed (L'Art poétique, III. 12): 'Il n'est point de Serpent, ni de Monstre odieux, / Qui par l'art imité ne puisse plaire aux yeux.' Boileau, Euvres complètes, ed. by Antoine Adam and Françoise Escal (Paris: Gallimard, 1966), p. 169.

15 See further Théâtre de la cruauté et récits sanglants en France: XVIe-XVIIe siècle, ed. by Christian Biet and Charlotte Bouteille-Meister (Paris: Robert Laffont, 2006); and Michael Meere, 'La Violence sur la scène classique: une question de (dé)gout?', in L'Invention du mauvais gout à l'âge classique, ed. by Jean-Christophe Abramovici and Carine Barbafieri (Leuven: Peeters, 2013), pp. 123-40. On death on the stage see also Essam Safty's La Mort tragique: Idéologie et mort dans la tragédie baroque en France (Paris: Harmattan, 2005).

${ }^{16}$ For a complementary study of the affective responses solicited by war-torn bodies, see Kjerstin Aukrust, “"J’ouvre mon estomac”: Agrippa d’Aubigné et le corps macabre’, in Corps Sanglants, Souffrants et Macabres, XVIe-XVIIe Siècles, ed. by Charlotte Bouteille-Meister and Kjerstin Aukrust (Paris: Presses Sorbonne Nouvelle, 2010), pp. 101-113.
} 
one that echoes, however imperfectly, the triumph embodied in the macabre wounds of La Ceppède's resurrected Saviour.

Moving away from defamiliarizing portraits of the hideous corpse, the final three articles interrogate aspects of problematic, living otherness that flourished in late sixteenthcentury France. The absence of a strong rule of law, and of national moral cohesion, made an ideal climate for vilifying speech-acts of the most aggressive kind. The 1570s and 80s saw endless libelles churned out by heresy hunters preaching to their own side about the vile depravity of the enemy. But who was the enemy? By the late 1580s, the war of words was far from a two-way pamphlet battle between Protestants and Catholics. The ultra-conservative Catholic Ligue expended increasing amounts of energy attacking religious moderates, collectively reviled under the nebulous term politique and similarly opaque insults. As studies have shown, the Ligue's outbursts were far from spontaneous, but carefully crafted to fly on the back of existing social, religious and juridical practices. ${ }^{17}$

Emma Claussen looks further at the rhetorical mechanics of vilification through a close study of two ligueur pamphlets produced amid anarchy in Paris in 1589. Here, politique and vilain are the most salient instrumental terms, establishing a web of vile associations that amplify all 'heresy' the Ligue so detests in its opponents: oath-breaking, dishonesty, hypocrisy, servile sinfulness, and low social status. Where such intense revilement proved resistant to falsification, was where the Ligue's supporters would find it an approximately rightful interpretation of the actions of those who continued to support King Henri III: the man the Ligue held responsible for the double assassination of its champions, the Duc de Guise and the Cardinal de Lorraine in 1588. Claussen's philologically oriented reading avoids overstressing the non-propositional dimension of Ligue-sponsored libels, without denying the importance of performative 'hate speech' designed to anger the ligueur faithful and to compel loyalty to the so-called 'Sainte Union' of the True Church. Modern scholarship has shown how the act of name-calling eventually advertises itself as a false consciousness, to be reinterpreted as vile slander, and not only by those directly vilified. ${ }^{18}$ One might thus situate ligueur hate speech as the culmination of an anti-eloquent strain of the French vernacular indirectly threatening Pléiadic initiatives to edify the French language. ${ }^{19}$ The problem of linguistic uncleanliness would linger on into the seventeenth century, as testified by the founders of the Académie française ${ }^{20}$ Yet Claussen's focus on the keywords vilain and politique in their socio-political functions also usefully attunes us to latent class anxieties at the climax of France's late sixteenth-century wars - namely the Ligue's call to arms against an entire caste of wealthy, would-be statesmen, deemed as unfit for government as the vile peasant: the proverbial vilain.

Philological scrutiny of vilains also lies at the heart of Marie-Claire Thomine-Bichard's article. Here, the cultural locus shifts from the capital to the province of Brittany, as portrayed through a number of rustic contes written by the nobleman and jurist Noël Du Fail that span the second half of the sixteenth century. Through close reading of Du Fail's work, ThomineBichard adroitly exposes what lies beneath the author's jovial, paternalistic amusement with stories about bumbling rustics in his region. The teasing caricatures of the vilain in Du Fail's contes emerge coterminously with an ambivalent critique of myths surrounding noble lineage.

\footnotetext{
${ }^{17}$ See particularly Tatiana Baranova, À coups de libelles: une culture politique au temps des guerres de religion (1562-1598) (Geneva: Droz, 2012), pp. 144-5. For a comparable seventeenth-century study of libel, see Christian Jouhaud, Mazarinades. La Fronde des mots (Paris: Aubier, 1985).

18 See Emily Butterworth, Poisoned Words: Slander and Satire in Early Modern France (London: Legenda, 2006).

${ }^{19}$ See further Peter Frei, François Rabelais et le scandale de la modernité: pour une herméneutique de l'obscène renaissant (Geneva: Droz, 2015), especially pp. 146-67.

${ }^{20}$ At its foundation in 1634, the Académie's core purpose was 'nettoyer la Langue des ordures qu'elle avoit contractées', as stated in Paul Pellisson-Fontanier's Relation contenant l'histoire de l'Académie françoise (Paris: T. Jolly, 1672), p. 26.
} 
Thomine-Bichard captures the awkward laughter of the early modern landowning gentilhomme, torn between a certain admiration of the 'natural' folly displayed by his lowly neighbours and a reluctance to believe that they are of one and the same humanity as he. ${ }^{21} \mathrm{Du}$ Fail's literary career spanned a period which saw the first fruits of a longue durée challenge to old-noble claims of socio-political and cultural hegemony. As Thomine-Bichard's study shows, this challenge provoked another variant of linguistic othering: namely the marked attempts by traditional gentilshommes to direct the adjective vilain specifically at those alleged to be usurping noble privileges, 'ces gentilshommes de nom, et vilains par effet.' As such, Du Fail offers a literary excursus of a juridical conundrum: whether class distinctions between privileged nobles and vile commoners were really (ever) as immutable as the many proverbial noble-vilain dichotomies made them out to be.

Finally, the term vilain occupies a pivotal position in Neil Kenny's analysis of incarnate knowledge in late sixteenth-century merchant literature. The vile human body returns, once again, now in the provincial setting of Poitiers, and in the profuse discours bigarré authored by the printer Guillaume Bouchet (c. 1513-94) in three volumes known as Les Serées (158498). Complementing the approaches of Thomine-Bichard and Claussen, Kenny shows how a keyword analysis reveals concerted interest in three coextensive strands of vileness - the social, the moral, and the scatological. Modelled loosely on the Platonic symposium, Bouchet's Les Serées purports to record the after-dinner conversations of a circle of poitevin merchants and other professionals, continually haunted, like Montaigne, by the ravages of a monstrous war. Strong notes of disgust are sounded when a pungent dreamer appears on the scene with 'paroles puantes'. Here, then, is a different kind of disruption of 'clean' speech to that explored by Claussen. Expressions of disgust, as modern critics have suggested, often serve to maintain and reinforce social barriers, hierarchies and decorum; ${ }^{22}$ but that is only a partial reflection of what going on in Bouchet's text. Here, unexpectedly, an unwanted Other who exceeds the acceptable opens up new avenues of conversation - and thus the possibility of 'thinking otherwise' (as Michel de Certeau puts it), ${ }^{23}$ through the incongruous or paradoxical half-openings of the merchants' discourse. As Kenny argues, Bouchet's vile dreamer enables his readers to question whether knowledge is really 'out there', beyond the immediately contingent. Echoing Rabelais, Bouchet's text plays on its constant framing of dirty and malodorous human flesh. It thereby produces an embodied, social and sceptical process of knowing that would have still had currency at the time of Descartes.

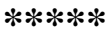

In a number of different contexts, early modern writers were drawn to reconsider some commonplace attributes of vileness - particularly in settings where a vile being, body or object seemed to have the beginnings of a positive value, be it heuristic (Rabelais, Montaigne, Bouchet) or paradoxical (Lemaire de Belges). Separating the precious from the vile proved to be a complex poetic enterprise, fraught with aesthetic and moral challenges, as the works of Ronsard, La Ceppède and Corneille variously attest. In other settings, however, the distinction of vile and non-vile appeared arrestingly, even dubiously clear-cut. Where class strife was a prevalent undertone in late sixteenth-century narrative and polemic, age-old couplings of the vile - low morals and low social status - were resolutely reinforced (Du Fail; ligueur pamphlets). Moving along and between these differing contexts and trends, this special issue

\footnotetext{
${ }^{21}$ A continuation of a medieval trend: see Kathryn Gravdal, Vilain and Courtois: Transgressive Parody in French Literature of the 12th and 13th Centuries (Lincoln NB: University of Nebraska Press, 1989).

${ }^{22}$ See Eschenbaum and Correll, Disgust in Early Modern English Literature, 'Introduction'; more generally William Miller, The Anatomy of Disgust (Cambridge MA: Harvard University Press, 2009).

${ }^{23}$ See Certeau, Heterologies: Discourse on the Other (Manchester: Manchester University Press, 1986), p. 194.
} 
aims to show how vileness in early modern France amounted to much more than a large, loose family of words, fears and prejudices. Vileness, one might say, captured the early modern mind most intently where and when it illuminated the increasingly visible, but seemingly intractable problem of calibrating moral and aesthetic categories with those of a changing socio-political hierarchy. The studies collated here offer new viewpoints on this wider puzzlement of early modern French literature and thought, as well as fresh and focused insights on specific variations of the vile.

\section{BIOGRAPHICAL NOTES}

Jonathan Patterson is Career Development Fellow in French at St Hilda's College Oxford. He is the author of Representing Avarice in Late Renaissance France (Oxford: Oxford University Press, 2015). His research explores connections between literature, social class, morality and law, as reflected in recent articles on Rabelais, Pierre Matthieu, Pierre de L'Estoile and Charles Loyseau. He is currently preparing an interdisciplinary study of villainy, from François Villon to Shakespeare.

Address: St Hilda’s College

Emilia Wilton-Godberfforde is a Lecturer in French at The Open University and has specialised in French theatre in the early modern period. She is author of Mendacity and the Figure of the Liar in Seventeenth-Century French Comedy (New York: Routledge, 2017). Her current project examines suicide in seventeenth-century drama. She has published articles on Molière, Rotrou and Tristan L'Hermite and has written on Bernard Lamy and Pierre Nicole for the 2017 edited collection in Yale French Studies entitled Guilty Pleasures: Theater, Piety and Morality in Seventeenth-Century France. Her research interests include dramatic theory, reception and audience response; theories of the comic; gender studies and translation studies.

Address: 73 Cunliffe Close, Oxford, OX2 7BJ, UK 